$\left[\begin{array}{ll}\text { Jpn. J. Hosp. Pharm. } \\ \hdashline 21(2) & 115-123 \\ \text { 䑳 } & \text { (1995) }\end{array}\right]$

\title{
小児用安全容器の透湿性
}

\author{
日高正人*, 田中淑子, 渡辺 敦, 杉原正泰 \\ 東京女子医科大学病院薬剤部†
}

\section{Water Vapor Permeation of Child Resistant Package}

\author{
Masato Hidaka*, Yoshiko Tanaka, Atsushi Watanabe \\ and MASAYASU SUgIHARA \\ Pharmaceutical Department, Tokyo Women's Medical College $\dagger$
}

$\left(\begin{array}{l}\text { Received September 20, } 1994 \\ \text { Accepted January 31, } 1995\end{array}\right)$

\begin{abstract}
The water vapor permeation behavior of the child resistant package (CRP) with a pressand-turn closure, the polyethylene bottle with a screw cap and the glass bottle with a screw cap was investigated. The water vapor permeation increased in the order of the glass bottle, polyethylene bottle and CRP. The amount of water vapor permeated through the CRP showed a linear increment with the passage of time. The effect of applied sealing torques on the water vapor permeation was also investigated. There was not affect on the water vapor permeation of glass bottle and little influence on the of the polyethylene bottle. On the contrary, the water vapor permeation of the CRP showed dependency on the applied sealing torque. These results suggest that the differences in water vapor permeation were due to the specific structure of the CRP closure. Additionally revealed was that in the CRP the relationship between the log applied sealing torque and the water vapor permeation rate produced a nearstraight curve.
\end{abstract}

Keywords — child resistant package, water vapor permeation, press and turn closure, sealing torque

\section{緒喜}

医薬品の包装は, 医薬品に要求される高い有効 性, 安全性, 安定性の保持の面, および調剤や患 者使用時の便利性の面において非常に大きな役割 を果たしている．包装の目的の一つとして，内容 物の保護, すなわち(1)医薬品が光, 温度, 湿度, ガス などの物理化学的因子により受ける変質, 劣化の 防止，(2)輸送時に受ける振動，落下,衝撃, 圧縮な

†東京都新宿区河田町 8-1；8-1, Kawada-cho, Shinjuku-ku, Tokyo, 162 Japan.
ぞの障害から医薬品及び容器を守る破損防止，(3) 微生物, 昆虫などの侵入, 異物の混入; 犯罪行為 などにより侵されることを防ぐ接触防止が考えら れる. 特にわが国は梅雨期を有するため, 環境湿 度は劣化に関係する環境ストレスの中でも重点的 に検討されるべさ因子である，吸湿に伴う固形製 剤の特性の変化としては, (1)変色, 湿潤・潮解・ 固化, 変形・ひび割れなどの官能的な変化，(2)主 薬の分解, 崩壊時間の遅延, 溶出性の低下, 錠剂 硬度の低下, 散剂流動性の低下などの理化学的な 変化，(3)カビ発生などが知られている。これらの 変質や劣化は医薬品の使命である薬効に大きく影 
響するためその防止は必須であり，吸湿を防止し て医薬品の品質を長期間保証するための防湿包装 の検討が重要となる.

一方, 最近の日本中毒情報センターへの中毒に 関する問い合わせにおいて，5才未満の幼小児に 関する問い合わせが約 8 割を占めている， と報告 されている1). 原因物質は, タバコ, 農薬, 洗剤, 化粧品など様々であるが, 医薬品もその上位を占 めている，中毒量に達する医薬品を誤领した場合 は症状も重く，死に至ることも多い，従って医薬 品の幼小児に対する中毒の防止対策が必要であ る.アメリカに拈いては1970年にいち早く，毒性 容器防止法 (PPPA : Poison Prevention Packaging Act）を制定し2,3)，1972年よりアスピリ ン製剂他十数品目に対し, CRP (Child Resistant Package : 小児用安全容器) の義務付けが 法政化されている。CRPは，5才以下の小児が, ある一定時間内に容器を開け，中毒量までの分量 を取り出すのが困難であるが，一方大人には開け やすい包装であると定義されている4,5).

包装材料には，金属，ガラス，ゴム，プラスチ ックと多種あり，これらが組み合わされた医薬 品容器も金属缶, ガラス瓶，ストリップ・パック (Strip pack : SP), プレススルーパック(Pressthrough pack : PTP) 等多数存在する.これら の透湿性は一様ではないため, 防湿包装の設計に はこれら容器, 材料の透湿性を検討する必要があ る. しかし，膜や材料の透湿性に関する研究報 告6) は多数みられるが，実際に用いられる包装形 態における透湿性に関する報告?は未だ少ない。 今回は CRP の防湿性について, Screw cap の ポリェチレン容器およびガラス容器と比較し, 容 器の材質およびキャップ構造の違いが防湿性にど のように影響するか検討を行った。

\section{実 験 の 部}

\section{1. 試料}

小児用安全容器は, reclosable packages（蓋 あるいは栓を用いた容器）と non-reclosable packages（SP，PTP）に大別される8) が，一般 に安全キャップを用いたものが， reclosable な 安全容器であり，Fig. 1 に示した 5 種類が知ら れている，わが国では，(1)の天面を押しながら回 す(Press-and-turn型) キャップを用いた CRP が多くみられることから, 本実験で使用するCRP も Press-and-turn 型安全キャップを用いた容 器とした。使用した CRP および比較対照として 使用した Screw cap のポリエチレン容器および ガラス容器の概要を Table 1 に示した.

試料容器 A-1 および A-2 は CRP であり, 容器部分の材質は高密度ポリエチレン製（平均肉 厚 $1.0 \mathrm{~mm})$, キャップはポリプロピレン製 $(2$ 層）で，パッキングに発泡ポリエチレンシート $1.0 \mathrm{~mm}$ (ハイシート)を用いている. 各々の重量 は35.6および $52.4 \mathrm{~g}$ ，容量は 30 および $70.2 \mathrm{ml} て ゙$ ある、A-1 および A-2 の構造と寸法を Fig. 2 に示した.

試料容器 A-1 および A-2 は Fig. 2 右サイ ドに示したように，外キャップと内キャップの二 重構造を有している. 外キャップの内側と肩部に 2 種の凸リブがあり，内キャップにそれに対応す るスライドリブと凸リブが存在する，閉栓する時 は，外キャップの内周上にある凸りブが内キャッ プのスライドリブにかかり，内キャップと外キャ ップが連動する. 開栓する時は, 外キャップに適 当な下向きの力を加えながら回さないと，外キャ ップ全周上の凸リブと内キャップ肩部にある凸リ ブが連結しないため, 外キャップの回転が内キャ
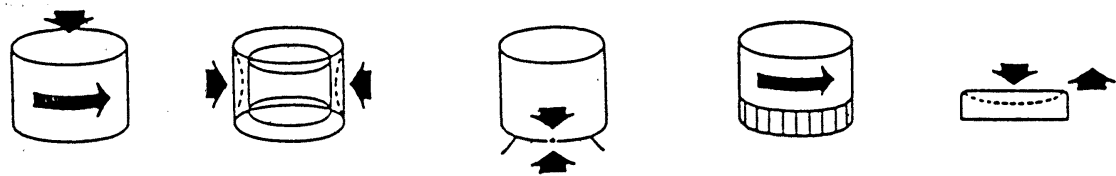

Press-and-turn Squeeze-and-turn Combination-lock Restraining ring Press-and-lift

Fig. 1. Five Basic Types of Safety Closures 
Table 1. Materials and Characteristics of Containers

Sample No. Volume(ml) Materials of bottle Materials of cap Materials of packing Kinds of Cap

\begin{tabular}{|c|c|c|c|c|c|}
\hline$A \cdot 1$ & 30.0 & HDPE" & PP”(Two-piece) & Foamed PE seat & Press and turn \\
\hline$A \cdot 2$ & 70.2 & HDPE & PP••(Two-piece) & Foamed PE seat & Press and turn \\
\hline B-1 & 36.0 & HDPE & PP"• & Flexible PVC liner & Screw \\
\hline B.2 & 70.2 & HDPE" & PP"* & Flexible PVC liner & Screw \\
\hline C & 50.0 & Glass”“ & Steal & Gum liner & Screw \\
\hline
\end{tabular}

- High density polyethylene

- Polypropylene

... JIS R3522 PS5

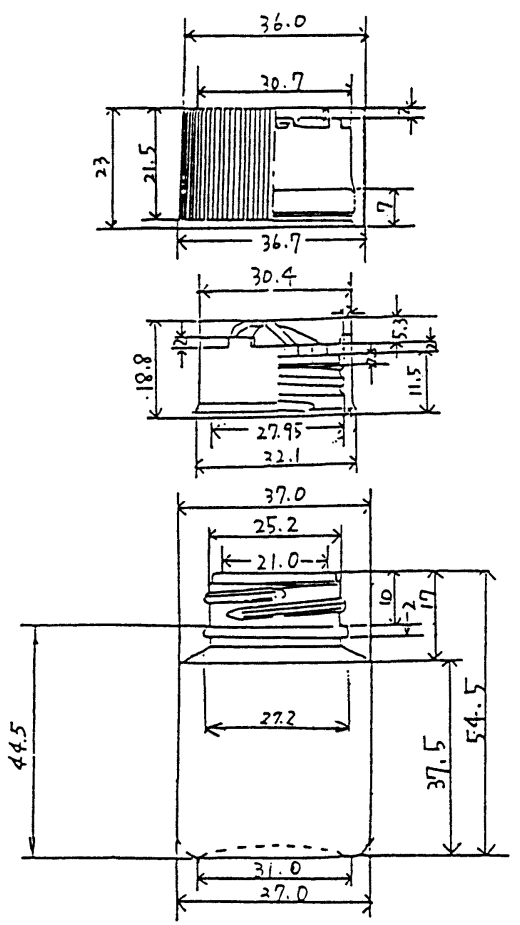

A-1

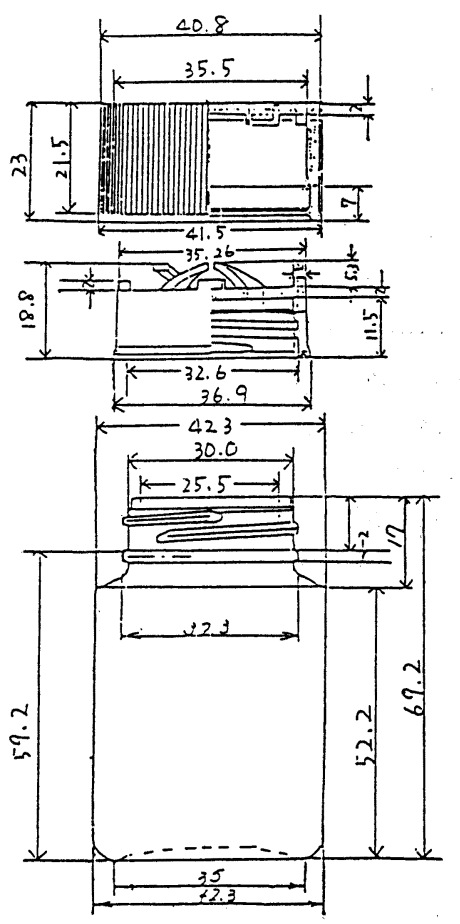

A-2
(1) outer cap

(2) inner cap

(3) slide rib of inner cap
(4) 凸rib of inner cap

(5) 凸rib of outer cap

(6) bottle

Structure of Press and Turn Cap

Fig. 2. Schematic Diagram of CRPs 


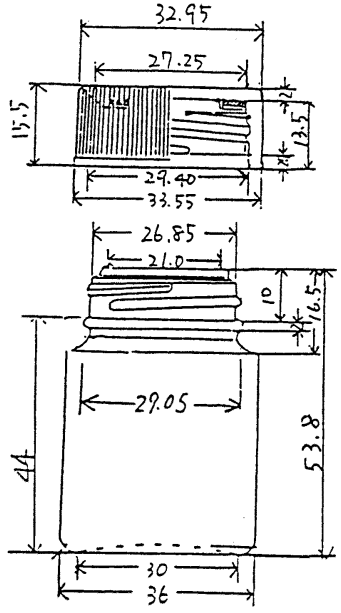

B-1
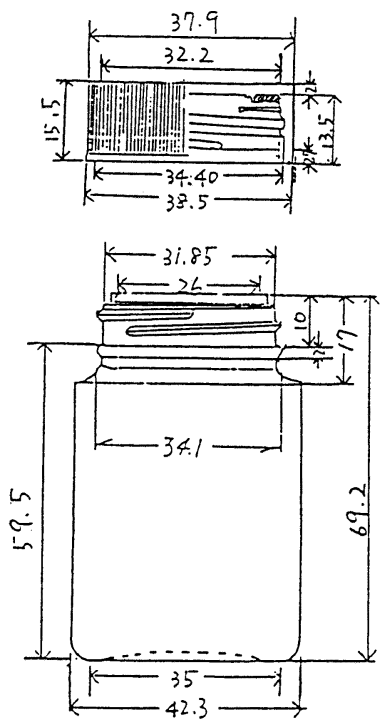

B-2
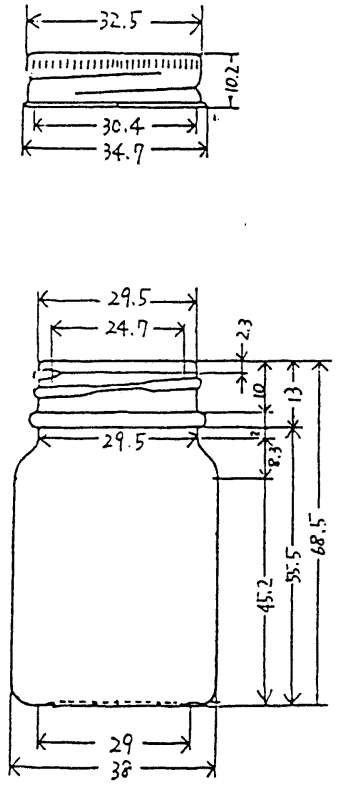

C

Fig. 3. Schematic Diagram of Polyethylene Bottles and Glass Bottle

ップに伝達されず開くことが不可能な仕組みであ

る.

試料容器 B-1 および B-2 は Screw 型キャッ プ構造を有する容器で, その概要は Table 1 に 示してある．Aと同じく容器部分の材質は高密度 ポリエチレン製（平均肉厚 $1.0 \mathrm{~mm}$ )，キャップは ポリプロピレン製でパッキン材に軟質塩化ビニー ルライニングを用いている．各々の重量は30およ

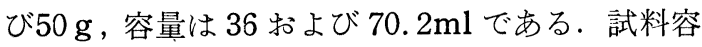
器 Cは Table 1 に示したような概要の Screw 型 キャップ構造を有するJJS 規格ガラス瓶 5 号であ り, 容器部分の材質は軟質硝子製, キャップはス チール製で内面ゴムライニングを用いている，重 量は71g, 容量は $50 \mathrm{ml}$ である。B-1，B-2 および Cの構造と寸法を Fig. 3 に示した.

\section{2. 透湿量の測定方法}

透湿量測定法として重量法9)である JIS Z 9222 を用いた (Fig. 4). 試料容器中に, 容器容量の 約半分量無水塩化カルシウムを充填し, キャップ は $5,10,15,20 の 4$ 種の強さの閉栓トルク $(\mathrm{kg}$ ・ $\mathrm{cm}$ )を用いて閉栓し, 透湿量測定の試料とした. 試料を約 $40^{\circ} \mathrm{C}$ になるまで徐々に一様に予熱した

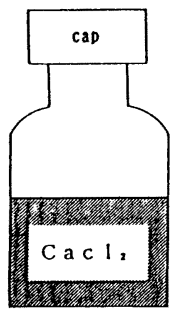

bottle

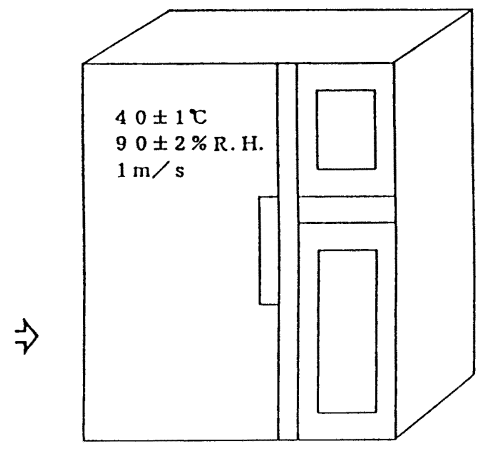

thetnostat-hygrostat lest chanber
Fig. 4. Testing Method (JIS Z0222) of the Water Vapor Permeation

後, 試料の重量を測定し, 恒温恒湿装置内（ナガ ノ科学 LH-20-01, 温度 $40 \pm 1^{\circ} \mathrm{C}$, 相対湿度 $90 \pm$ $2 \%$, 風速 $1 \mathrm{~m} / \mathrm{s})$ に保存した. 経時的 $(1,3$,

$7 ， 14 ， 21$ 日後) に試料を取り出して重量を測定 し, 保存前に測定しておいた試料の重量との差か ら増加重量を求め, 透湿量とした. 試験は各々 3 個の試料容器を用いて行い, その平均を求めた。

\section{3. 閉栓トルクの設定方法}

閉栓トルクの設定は, Fig. 5 に示すトルクメー 

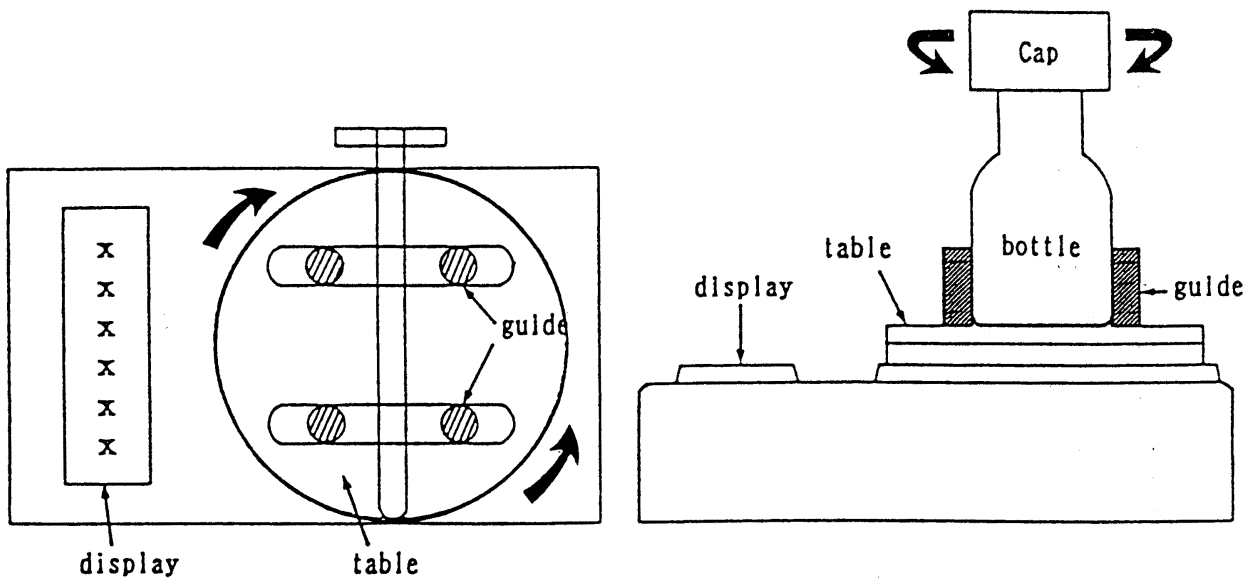

Fig. 5. Schematic Illustration for the Testing Method of the Torque Meter

ター(TOHNICHI, TYPE EOT)を用いて行っ

た.すなわち, 試料容器の容器部分をテーブル上 の 4 つのガイドで固定した後，キャップを右方向 に静かに回し，ディスプレイの表示が設定閉栓ト ルクになるまで閉栓した。

\section{結果および考察}

\section{1. 各試料容器における透湿量の経時的な変化} 各試料容器に打ける透湿量の経時的な変化を Fig. 6 に示した.

3 種の試料容器を比較すると, 透湿量はガラス 容器, ポリエチレン容器, CRP の順に大きい值
を示した。ガラス容器であるCでは21日間にわた りほとんど透湿量の増大は認められず, この容器 の透湿性は非常に低いことが認められた．しか し, 容器部分やキャップ部分の材質が同じ試料容

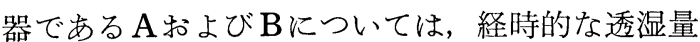
の増大が観察された，CRP であるAに打ける透 湿量和よびその経時的增加率は，Bと比較して著 しく大であり，CRP に打ける透湿挙動は経時的 に直線的な増加を示した。試料容器 $\mathrm{A}$ と B の容器 部分の材質および肉厚は同じであり，またA-1 と B-1，A-2 と B-2 は容器容量がほぼ同じで表面 積も汇同じであることから, 試料容器 $\mathrm{A}$ と $\mathrm{B}$ に

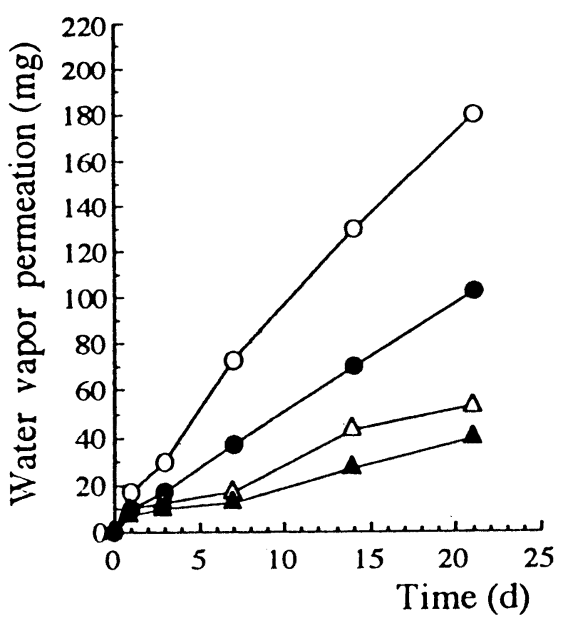

A-1

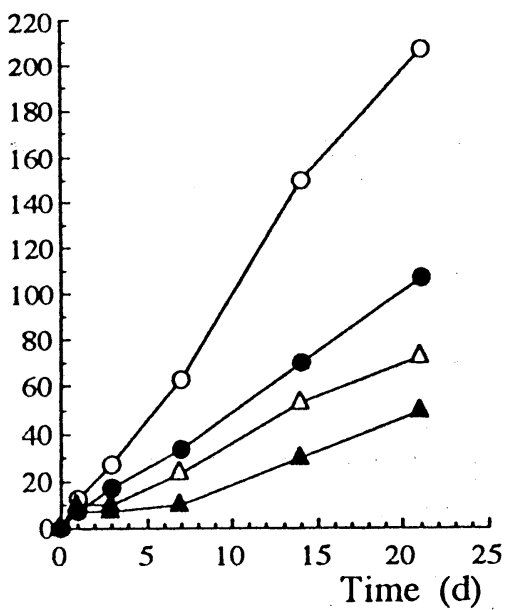

A-2 

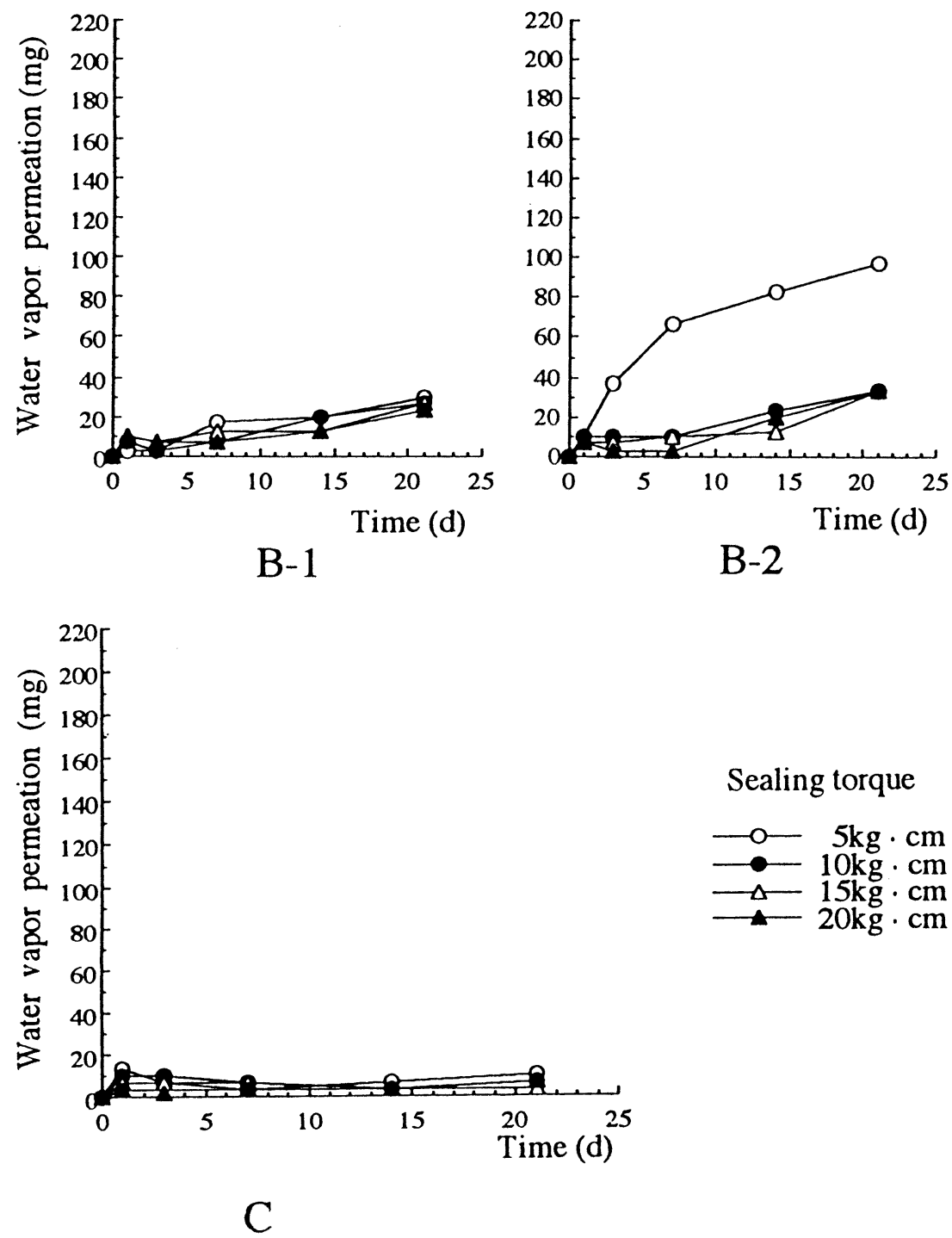

\section{Sealing torque}

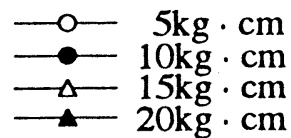

Fig. 6. Water Vapor Permeation Behavior of Sample Bottles under Several Sealing Torques $\left(40 \pm 1^{\circ} \mathrm{C}\right.$ and $90 \pm 2 \%$ R.H., $\left.\mathrm{n}=3\right)$

おける透湿挙動の差はキャップ部分の構造の違い によるものと考兄られた。ささらに, 試料容器 B Cの差は, Cの容器材質が水蒸気不透過であるガ ラスであるためと考えられた。

\section{2. 透湿量への閉栓トルク值の大きさの影響}

Fig. 7 には各試料容器に打ける 21 日後の透湿 量と, 閉栓トルク值の大きさとの関係を示した. ガラス容器のCでは，いずれのトルク值でも透湿 量が $20 \mathrm{mg}$ 以下と低い值であった。 また，試料容

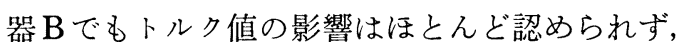
さらに容器容量の違いによる透湿量の差もわずか であった、 B-1 よりも容器容量が大である B-2 で，閉栓トルク值が $5 \mathrm{~kg} ・ \mathrm{~cm}$ の時のみ高い透湿 量を示したが, 他のトルク值のときは B-1 と B-2 に差が認められないことから，容器の大きさすな わち容器ポリエチンン膜からの透湿量は小であっ た。このことから，B-2 に打壮る閉栓トルク值が $5 \mathrm{~kg} \cdot \mathrm{cm}$ の時の高い透湿量は, 容器材質の高分 


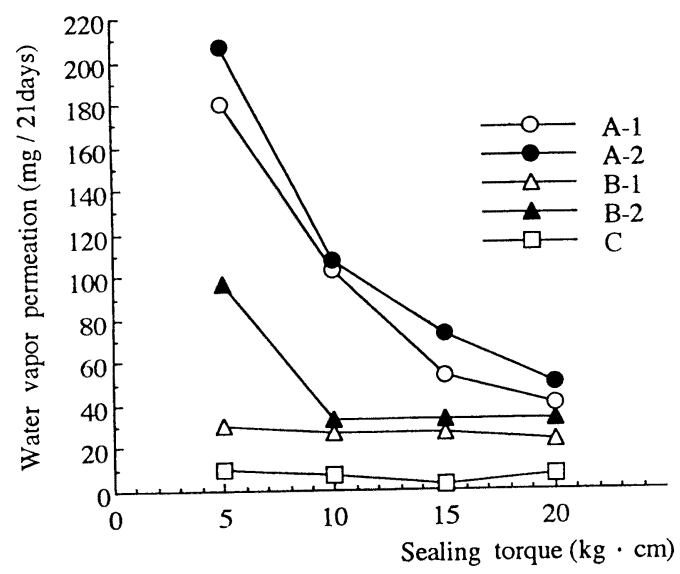

Fig. 7. Influences of the Sealing Torque on Water Vapor Permeation $\left(40 \pm 1^{\circ} \mathrm{C}\right.$ and $90 \pm 2 \%$ R.H., $\mathrm{n}=3$ )

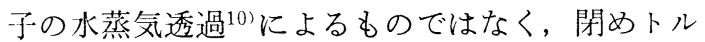
クが小さいためキャップの締まりがゆるく, 容器 ロとライナー間のすき間から水蒸気の拡散が進ん だためと考えられた. 同じ $5 \mathrm{~kg} ・ \mathrm{~cm}$ の閉栓トル ク值でも B-1での透湿量が低いのは, 容器の口外 径が小さいためキャップの緩みが起きなかったも のと思われた．以上のことから，B-1 および B-2 のような種類の容器に扮いて高い防湿機能を得る

A-1

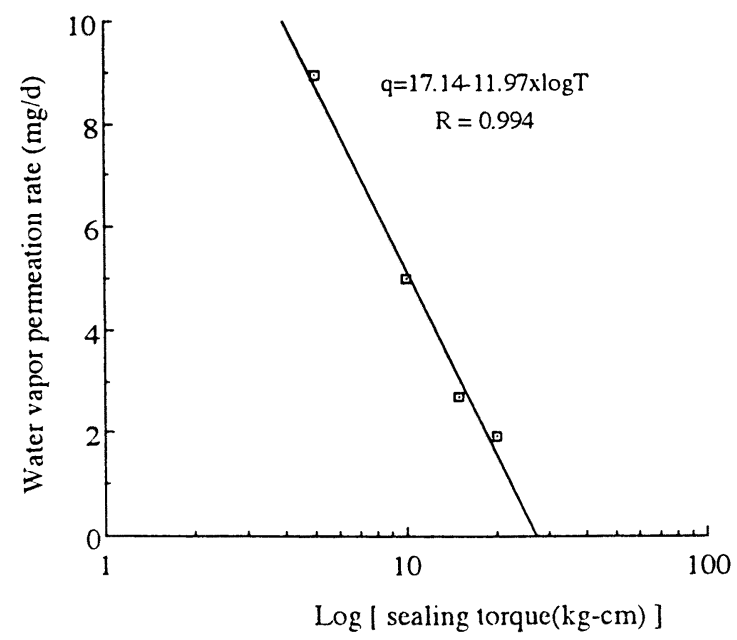

ためには, $10 \mathrm{~kg} ・ \mathrm{~cm}$ 以上の閉栓トルクが必要で あった。

一方，CRPのAでは閉栓トルク值が小さいほ ど吸湿量は大きく，透湿量は閉栓卜ルク值に依存 していることが明らかとなったＡ－1 と A-2の 各閉栓トルク值に䋆壮る透湿量を比較すると大き な差は認められなかったが，容量・口外径の大き いA-2の方が若干大きな透湿量を示していた．特 に閉栓トルク值 $5,10 \mathrm{~kg} ・ \mathrm{~cm}$ に打けるAの吸湿 量は大であり，この閉栓トルク值では水蒸気の侵 入を防止するのは困難であった：Aに括いて高い 防湿機能を得るためには, $20 \mathrm{~kg} ・ \mathrm{~cm}$ 以上の閉栓 トルクが必要と思われた。容器材質が葟ぼ同じ試 料容器の A と Bではすべての閉栓トルク值におい てAの方の透湿量が高かった．この原因の一つと してパッキング材質および形状（Aで用いた発泡 ポリェチレンシートよりも， B の PVC ライニン グが透湿に関する表面積・断面積が小さい) の影 響が考えられた。 また，CRP は閉栓トルク值， つまりキャップのしめ強弱による透湿量の変動 が，他のガラス容器やポリエチレン容器よりも大 であった。これは CRP の構造に拈いて，Fig. 2 に示すキャップ部分のスライドリブ部が開放状態 になっていることに起因するもので，その特異な

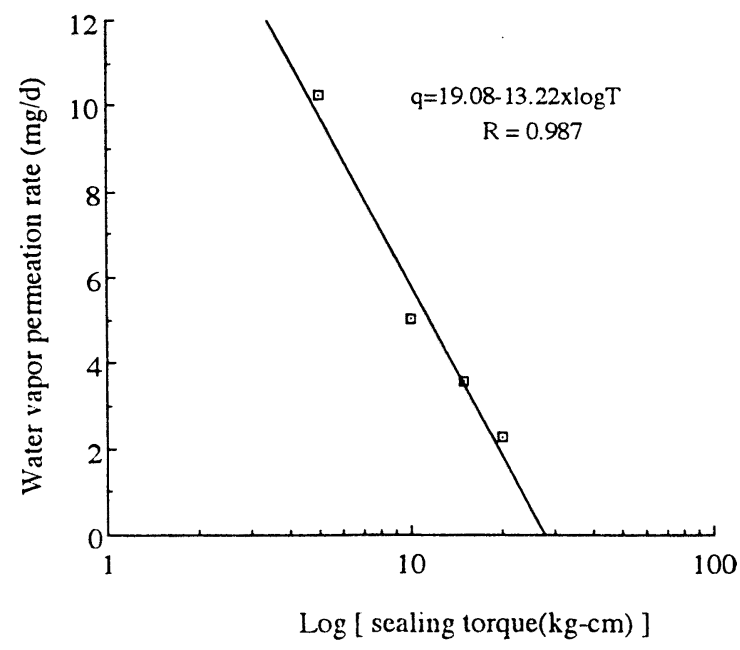

Fig. 8. Correlation between the Sealing Torque and the Water Vapor Permeation Rate $\left(40 \pm 1^{\circ} \mathrm{C}\right.$ and $90 \pm 2 \%$ R.H., $\mathrm{n}=3$ ) 
キャップ構造のためにキャップ部分からの透湿が 主となり, 閉栓トルク值が容器の透湿量に大きく 影響したものと考えられた。

\section{CRP における透湿量と閉栓トルク値の関} 係

試料容器Aでは, Fig. 6 亿示したよらに透湿量 は時間に対して直線的に増大したことから，21日 後の透湿量を日数で除して 1 日あたりの透湿速度 $\mathrm{q}(\mathrm{g} / \mathrm{day})$ を求め, 閉栓トルク值 $\mathrm{T}(\mathrm{kg} \cdot \mathrm{cm})$ と の間の相関を検討した．Fig. 8に示したように 閉栓トルク值の対数に対して透湿速度をプロット すると良好な直線関係が認められ，今回用いた CRP 容器では, 温度, 外湿度一定のとき, 閉栓卜 ルク值 $\mathbf{T}$ と単位時間あたりの透湿量 $\mathbf{q}$ との間に(1) 式が成立することが認められた。

$$
\mathrm{q}=\mathrm{a}+\mathrm{b} \log \mathrm{T}
$$

定数 a は, 閉栓トルクが限りなく 0 に近い,つ まり完全たシールされてない状態の時の透湿速度 と考えられ, 容器材質の透湿および容器口とライ ナー間のすき間からの水蒸気拡散が主たるもので ある. そのため, 容器容量(容器の表面積)および 容器口とライナー間のすき間を形勢するキャップ の口径が影響すると考えられた。実際, 定数、は 試料容器 A-1 で $17.14, A-2$ で 19.08 と, 容器 容量やキャップロ径が大である A-2 の方が大き な值であった．定数 $\mathrm{b}$ は負の值で, 透湿速度の閉 栓トルク值变化への依存性を示しており, この值 が大きいほど閉栓トルク值のわずかな変化が透湿 速度に大きく影響することになるので，適切な閉 栓トルクの設定に注意が必要である. 定数 bは, A-1 で 11.97, A-2 で 13.22 であった.

\section{結 語}

本実験の試料容器では, 透湿量はガラス容器, ポリェチレン容器, CRP の順に大きい值を示し た. 最近では, Press-and-turn 方式の CRPに おいてもスライドリブ部が密閉構造となっている タイプなどが開発されてはいるが, CRP 容器に 医薬品を保存する際は，開封性，小児安全性のみ ならず透湿性を十分考慮する必要があると考えら れた，CRP において透湿量は閉栓トルク值の影
響を大きく受け，高い防湿性を得るためにはガラ ス容器や一般ポリェチレン容器と比較してょり大 きな閉栓トルク值を設定しなければならないこと が明らかとなった。しかし, 閉栓トルク值は透湿 性のみでなくキャップの開封性に大きな影響を与 えることから，キャップの開封性も考慮した適正 な閉栓トルク値の設定が重要と考えられる. 閉栓 トルク值が大きくなるとキャップを開けるための 開栓トルク值も大きくなり，CRP が高齢者や女 性には開封しにくいという要因にもなる可能性が ある. 適正閉栓トルク值を左右する容器側の要因 の一つにキャップの直径などが考えられている.

つまり, 大きな外径のびんは所定の保護性を確保 するために大きなトルク值を要するが，一方で同 一のトルク值ならキャップ直径の大きいほうが開 封が容易となる ${ }^{11)}$. USPによるとスクリューキャ ップの外径 $\mathrm{D}_{\mathrm{c}}$ と適正トルク值 $\mathrm{T}_{\mathrm{a}}$ の関係は(2)式で 表されるといわれている.

$$
\mathrm{T}_{\mathrm{a}}=0.5 \mathrm{D}_{\mathrm{c}}
$$

(2)式から考えると，キャップ径の大きいA-2の 方が A-1よりも適正閉栓トルク值が大であるはず であるが，本実験で，高い防湿性を得るためには A-1 および A-2 とも $20 \mathrm{~kg} \cdot \mathrm{cm}$ 以上の閉栓トル クが必要であった. キャップ径の透湿量への影響 は今後さらに検討したいと考えている.

\section{引用文 献}

1）新谷 茂, 吉田敏治, 後藤京子, 石沢淳子, 山田 容子, 磯村千鶴, 島津恵子, 中毒研究, 2, 429 430 (1989).

2) Public Law 91-601 91st Congress S2162, Dec. (1970).

3) American Society for Testing and Materials, STP609 (1976).

4) 杉原正泰, 中毒研究, 5, 11-19 (1992).

5）杉原正泰, “医薬品の包装設計”, 杉原正泰編, 南 山堂, 東京, 1984, pp.107-124.

6) K. Nakabayashi, T. Shimamoto and H. Mima, Chem. Pharm. Bull., 28, 1090-1098; ibid., 28, 1099-1106; 中林 靖, 武田研究所報, 41, 114-140 (1982).

7）中林 靖, “保険薬局に打ける医薬品の品質管 理”, 大阪府衛生部大阪府薬剂師会編, 1975, pp. $2-17$. 
8）中林 靖,武田研究所報, 34, 569-585 (1975).

9）JIS Z 0222-1959「防湿包装容器の透湿度試験方 法」.

10）“化学便覧 応用編 改訂 2 版”，日本化学会編，
丸善, 東京, 1973. pp. 803-1062.

11）三浦秀雄, “医薬品包装の使用性とその評価”, 杉 原正泰編，講談社，東京，1990，pp. 200-202. 